\title{
PENGARUH MINAT BELAJAR TERHADAP KEMAMPUAN MEMBACA BAHASA INGGRIS SISWA
}

\author{
Miftahul Farid Mochamad Ahyar ${ }^{1}$, Fitri Senny Hapsari ${ }^{2}$, Isroyati ${ }^{3}$ \\ Universitas Indraprasta PGRI Jakarta ${ }^{1,2,3}$ \\ Miftahul_farid21@yahoo.com ${ }^{1}$
}

\begin{abstract}
ABSTRAK
Penelitian ini bertujuan untuk mengetahui pengaruh minat belajar terhadap kemampuan membaca Bahasa Inggris siswa Sekolah Menengah Kejuruan (SMK) swasta di Depok. Metode yang digunakan adalah metode survei dengan jumlah sampel sebanyak 40 siswa yang diambil dengan teknik random sampling dari tiga SMK Swasta di Kota Depok. Pengumpulan data minat belajar menggunakan kuesioner dengan bentuk rating scale, sedangkan kemampuan membaca Bahasa Inggris siswa disajikan dalam bentuk tes ulangan tertulis dengan soal pilihan ganda. Kedua instrumen tes terlebih dahulu divalidasi. Analisis data mengunakan analisis varians (ANAVA) dua arah dengan terlebih dahulu dilakukan uji normalitas dan uji homogenitas. Hasil penelitian terdapat pengaruh yang signifikan dari minat belajar terhadap kemampuan membaca Bahasa Inggris siswa dibuktikan dengan nilai $\rho$ value $=0.024<0,05$. Simpulan, minat belajar siswa berpengaruh secara signifikan terhadap kemampuan membaca Bahasa Inggris.
\end{abstract}

Kata Kunci: Bahasa Inggris, Kemampuan Membaca, Minat belajar

\begin{abstract}
This study aims to determine the effect of interest in learning on the ability to read English Vocational High School students in Depok. The method used was a survey method with a total sample of 40 students taken by random sampling technique from three private vocational schools in Depok. Learning interest data collection uses a questionnaire in the form of a rating scale, while the ability to read English students is presented in the form of a written test with multiple choice questions. Both test instruments are first validated. Data analysis uses two-way analysis of variance (ANAVA) by first testing the normality and homogeneity tests. The results of the study there is a significant influence of interest in learning on the ability to read English students proven by the value of $\rho$ value $=0.024<0.05$. In conclusion, student interest in learning has a significant effect on English reading ability.
\end{abstract}

Keywords: English, Reading Ability, Interest in Learning

\section{PENDAHULUAN}

Bahasa Inggris merupakan salah satu mata pelajaran yang wajib dipelajari oleh siswa di jenjang sekolah menengah kejuruan (SMK) baik negeri maupun swasta. Hal ini merupakan perwujudan komitmen pemerintah Indonesia dalam 
meningkatkan kualiatas sumber daya manusianya yang dimulai dari para pelajar untuk menguasai bahasa asing terutama bahasa Inggris guna mengahadapi era globalisasi yang saat ini terjadi dan masih besar kemungkinannya untuk berkembang.

Namun dalam rangka mempelajari Bahasa Inggris sebagai bahasa asing pertama yang digunakan di Indonesia, Bahasa Inggris memiliki tingkat kesulitan yang cukup kompleks untuk dikuasai. Terlebih terdapat kriteria yang meliputi empat keterampilan berbahasa, yaitu: menyimak, berbicara, membaca dan menulis yang wajib dipelajarpada pelajaran Bahasa Inggris dalam jenjang menengah ke atas termasuk SMK. Tentu perbedaan antara karakteristik dari kosakata dan tata bahasa menjadi tantangan tersendiri bagi siswa. Dari ke empat kemampuan di atas kemampuan membaca (reading ability) adalah salah satu kemampuan berbahasa yang dirasa sering dianggap sulit bagi siswa karena rumitnya tingkat permasalahan yang siswa temui dalam proses pembelajaran Bahasa Inggris di kelas.

Menurut Pratiwi (2015) membaca merupakan kegiatan berinteraksi dengan bahasa yang sudah disandikan ke dalam tulisan. Interaksi tersebut haruslah menghasilkan pemahaman (atas makna yang terkandung di dalam naskah sasaran) Pembaca berhadapan dengan kata-kata, frasa-frasa dan kalimat-kalimat serta media-media visual yang melengkapinya, yang membentuk satu keseluruhan naskah dengan tata-tulis yang dianut.

Menimbang bahwa membaca adalah kemampuan yang kompleks maka hal ini memberikan motivasi bagi penulis untuk menjadikannya sebagai tema penelitian karena kemampuan membaca (reading ability) sangatlah dipengaruhi oleh struktur bahasa, kosa kata dan faktor internal dari siswa seperti motivasi, keinginan dan minat belajar siswa.

Sebuah pernyata dari Hapsari (2015) menyebutkan Since English is Taught as foreign language, English is rarely used outside the classroom. Even in the classroom, not many students lack of practice it. Fenomena ini memang lumrah terjadi dan didasari kurangnya minat belajar pada siswa itu sendiri, sehingga sulit bagi siswa dapat meningkatkan kualitas kemampuan membaca mereka tanpa adanya minat belajar yang baik

Menurut Syah (2003) minat berarti kecenderungan dan gairah yang tinggi atau keinginan yang besar terhadap sesuatu. oleh karena itu dapat dikatakan minat belajar merupakan dorongan yang muncul dari dalam diri siswa yang merupakan motivasi internal maupun motivasi yang ada dalam situasi belajar (motivasi eksternal). Secara umum, minat belajar sebagai dorongan yang perlu ada dalam diri siswa yang merupakan motivasi internal maupun motivasi yang ada dalam situasi belajar (motivasi eksternal), yang dapat dimanipulasi dalam proses belajar.

Usman (2003) menjelaskan kondisi belajar mengajar yang efektif adalah adanya minat dan perhatian siswa dalam belajar. Dengan adanya minat siswa akan 
melakukan dan memperdalam apa yang menurutnya menarik, sehingga variable ini dirasa memberikan kontribusi yang besar terhadap proses belajar, seperti juga dinyatakan oleh Djamarah (2002) bahwa minat belajar cenderung menghasilkan prestasi belajar yang tinggi.

Memahami pengaruh postif dari minat belajar tentu hal ini menjadi elemen penting yang harus distimulasi oleh guru kepada siswa karena menurut Dimyati \& Mudjiono (2002) prinsip-prinsip yang berkaitan dengan perhatian dan motivasi perlu dibentuk dalam kegiatan belajar sehingga dapat menumbuhkan minat belajar siswa yang diharapkan dapat memaksimalkan potensi akademik siswa khususnya dalam penguasaan kemambuat membaca Bahasa Inggris.

\section{METODE PENELITIAN}

Penelitian ini menggunakan metode survei dengan pendekatan kuantitatif dan teknik analisis korelasional.Variabel dalam penelitian ini terdiri dari satu variabel bebas, yaitu Minat Belajar (X1) sedangkan variabel terikat adalah kemampuan membaca bahasa inggris (Y1).

Pengumpulan data dan informasi pada penelitian ini dilakukan dengan mengambil opini dari sejumlah besar orang dalam menanggapi suatu topik yang disajikan Sukmadinata (2013). Penelitian dilakukan di kelas XI Sekolah Menengah Kejuruan (SMK) Swasta di Kota Depok tahun pelajaran 2016/2017. Di wilayah ini terdapat 3 (tiga) buah SMK Swasta yang menjadi tempat penelitian, SMK Raflesia, SMK Karya Muda, dan SMK Setia Negara.

Sugiyono (2008) mengatakan bahwa populasi adalah wilayah generalisasi yang terdiri atas: obyek/subyek yang mempunyai kualitas dan karakteristik tertentu yang ditetapkan oleh peneliti untuk dipelajari dan kemudian ditarik kesimpulannya. Jumlah total dari populasi penelitian ini adalah 602 siswa dari total 13 rombongan belajar.

Penentuan sample penelitian ini mengacu pada pendapat Arikunto (2010) yaitu apabila obyek penelitian lebih besar dari 100 responden diambil 10\% sampai $15 \%$, atau 20\% sampai dengan 30\% tetapi apabila kurang dari 100 responden, maka responden atau sampel diambil seluruhnya. Berdasarkan teori tersebut maka sampel diperoleh dengan mengambil 10\% dari populasi. Dengan demikian maka jumlah sampel pada penelitian ini adalah 60,1 dibulatkan menjadi 60 siswa.

Perhitungan penetapan jumlah anggota sampel seperti tertera pada Tabel berikut:

Tabel 1

Penetapan Sampel Penelitian

\begin{tabular}{cccc}
\hline No & Nama Sekolah & Jumlah Siswa & Sample \\
\hline 1 & SMK Swasta Raflesia & 162 & 16 \\
\hline 2 & SMK Swasta Al-Muhtadin & 225 & 26 \\
\hline 3 & SMK Swasta Setia Negara & 184 & 18 \\
\hline & Total & 602 & 60 \\
\hline
\end{tabular}


Instrumen yang digunakan untuk mengumpulkan data tentang Minat Belajar adalah berbentuk kuesioner dengan menggunakan rating scale. Model rating scale yang digunakan dalam bentuk kontinum dengan 5 (lima) kategori, yaitu untuk butir pertanyaan bermakna positif maka nilai jawaban untuk Selalu = 5 , Sering $=4$, kadang-kadang $=3$, Pernah $=2$, dan Tidak Pernah $=1$. Sedangkan untuk butir pertanyaan bermakna negatif maka nilai jawaban untuk Selalu $=1$, Sering $=2$, kadang-kadang $=3$, Pernah $=4$, dan Tidak Pernah $=5$.

Sedangkan instrumen untuk mengumpulkan data dari kemampuan membaca siswa disajikan tes ulangan tertulis dengan soal berbentuk pilihan ganda sebanyak 25 butir dengan 5 pilihan jawaban. Adapun materi tes tersebut adalah wacana/teks bahasa Inggris dengan indikator: 1. Pemahaman terhadap kata, 2. Pemahaman terhadap makna kalimat, 3. Pemahaman terhadap isi bacaan.

Kesahihan atau validitas butir soal diuji dengan menggunakan koofiensi korelasi product moment. Untuk uji reabilitas koesioner penguasaan kosakata menggunakan rumus Alpha Cronbach. Setelah keseluruhan uji persyaratan analisis data dipenuhi dan diketahui data layak untuk diolah lebih lanjut, maka langkah berikutnya adalah menguji masing-masing hipotesis menggunakan teknik korelasi partial dan korelasi ganda, serta regresi linier sederhana dan regresi linier ganda. Perhitungan dan pengujian korelasi dan regresi baik partial maupun ganda akan digunakan bantuan program SPSS 20. Hasil perhitungan koefisien korelasi ganda bisa dilihat pada tabel Model Summary ${ }^{\mathrm{b}}$. Hasil perhitungan garis regresi bisa dilihat dari output program SPSS pada tabel Coefficients ${ }^{\mathrm{a}}$.

Hasil pengujian signifikansi regresi ganda bisa dilihat dari output program SPSS melalui analisis regresi yakni pada tabel ANOVA $^{\mathrm{b}}$ kolom $\mathrm{F}$ atau Sig. Kriteria signifikansinya adalah: Jika digunakan Kolom Sig, maka kriteria signifikansinya adalah:"jika Sig < 0,05 maka garis regresi tersebut signifikan”. Namun jika digunakan Kolom F, maka kriteria signifikansinya adalah: "jika $\mathrm{F}_{\text {hitung }}>\mathrm{F}_{\text {tabel }}$ maka garis regresi tersebut signifikan"

\section{HASIL DAN PEMBAHASAN}

Data minat belajar diperoleh dari kuisioner yang di jawab oleh 60 siswa dihasilkan skor terendah 61, skor tertinggi 111, skor rerata sebesar 89,47, median 90, modus sebesar 90, dan simpangan baku sebesar 13,916. Sedangkan banyaknya butir pertanyaan dalam instrumen pengukuran minat belajar tersebut adalah sebanyak 26 butir dimana skor maksimum tiap butir pertanyaan adalah 5, maka diperoleh skor rata-rata tiap pertanyaan adalah 3,441 atau 68,82\%. Hal ini menunjukkan bahwa rata-rata skor minat belajar termasuk sedang. Untuk tingkat penyebaran data, bisa dilihat dari angka simpangan baku yaitu sebesar 13,916 atau sama dengan $15,55 \%$ dari rata-rata. Hal ini menunjukkan bahwa perbedaan jawaban antar responden atas instrumen tersebut termasuk sedang, dan berarti minat belajar dari responden pada penelitian ini cukup beragam.

Data minat belajar antara nilai rata-rata dan dan median hampir sama, yaitu 89,47 dan 90. Hal ini menunjukkan bahwa data minat belajar pada penelitian 
ini cukup representatif. Sedangkan skor yang berada di atas rata-rata lebih banyak dibanding yang berada di bawah rata-rata, menunjukkan bahwa responden yang mempunyai minat belajar yang positif lebih banyak dibanding yang negatif. Histogram dari data tersebut bisa dilihat pada Gambar 1

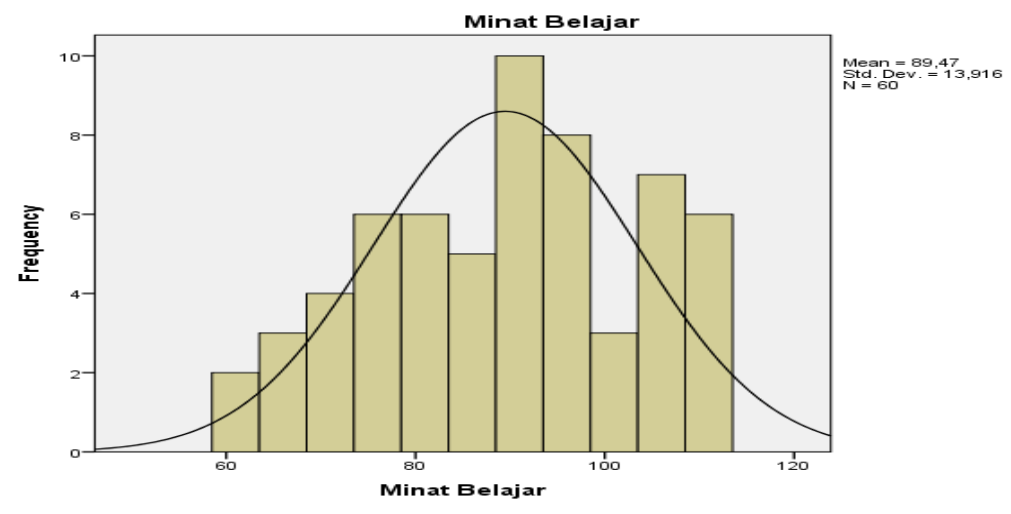

Gambar 1. Histogram Data Minat belajar

Dari deskripsi data, histrogram, dan poligon frekwensi dapat disimpulkan bahwa data Penguasaan kosakata yang dipeoleh pada penelitian ini memiliki sebaran yang cenderung normal.

Perhitungan juga dilakukan pada kelas yang diajar dengan media film dan strategi semantic mapping secara bersama-sama. Dalam kelompok ini diperoleh hasil nilai rata-rata 76,0 dengan nilai tengah 80,0 dan nilai yang sering muncul 80,0 Setelah mendapatkan hasil perhitungan statistic tersebut, maka uji normalitas dilakukan untuk mengetahui apakah data berdistribusi normal atau tidak. Uji normalitas data dengan menggunakan analisis Kolmogorov Smirnov menunjukkan bahwa semua data berdistribusi normal. Karena nilai sig pada ketiga kelompok diatas masing-masing diperoleh 0,205, 0,522 dan 0,333. Ketiga nilai tersebut lebih besar dari 0,05. Maka kesimpulannya semua data berdistribusi normal.

Uji homogenitas juga dilakukan untuk mengetahui apakah data bersifat homogeny. Dengan bantuan SPSS 15.0 dengan Levene's test, diperoleh nilai sig $0,120>0,05$ maka varian dikatakan homogeny.

Sedangkan data kemampuan membaca Bahasa inggris yang diperoleh dari responden mempunyai rata-rata 75,32 dengan simpangan baku 14,868, median sebesar 78,60, skor minimum 43 dan skor maksmum 95. Hal ini menunjukkan bahwa rata-rata kemampuan membaca Bahasa Inggris yang dimilliki responden termasuk sedang. Jika mempertimbangkan ketuntasan belajar dimana siswa dikatakan tuntas belajar jika nilai yang diperoleh di atas Kriteria Ketuntasan Minimal (KKM) yang ditetapkan oleh sekolah. Pada penelitian ini KKM mata pelajaran bahasa inggris kelas 10 di sekolah tempat penelitian adalah 75, maka banyaknya responden yag tuntas sebanyak 35 orang atau 58,33\%. Jadi jika dilihat 
dari ketuntasan belajar, maka kemampuan membaca Bahasa inggris yang dimilliki responden juga termasuk sedang.

Dari deskripsi tersebut juga dapat dilihat bahwa antara nilai rata-rata dan dan nilai tengah (median) hampir sama. Hal ini menunjukkan bahwa data kemampuan membaca siswa pada pelajaran bahasa inggris pada penelitian ini cukup representatif. Histogram dari data tersebut bisa dilihat pada Gambar 2

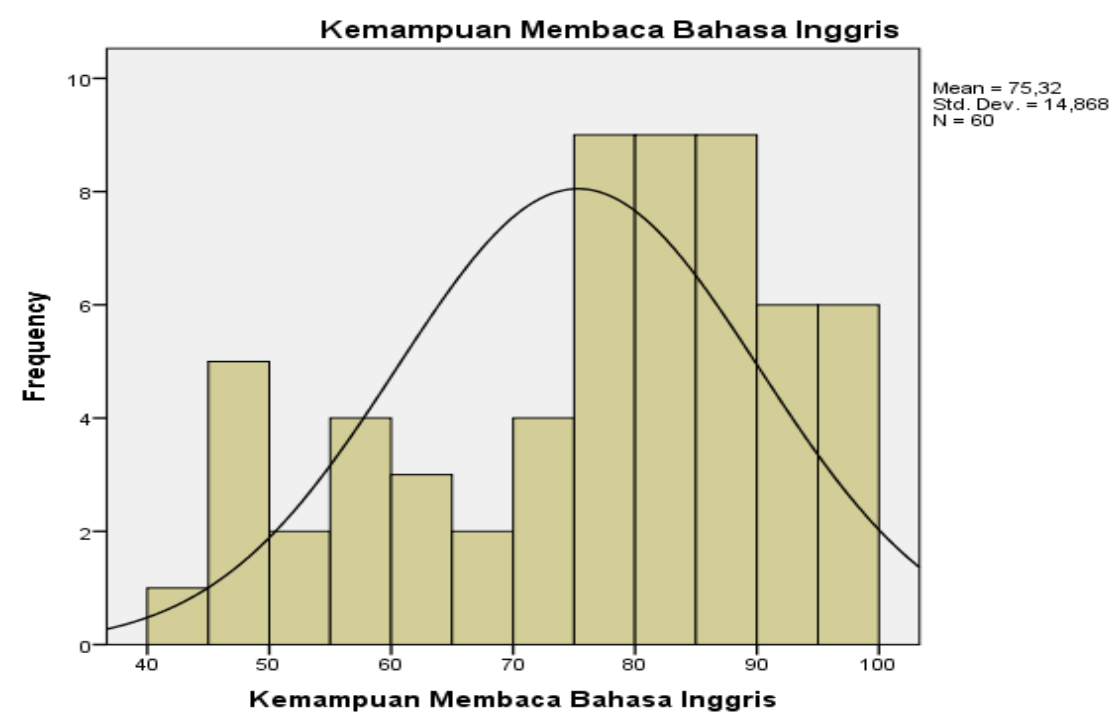

Gambar 2. Histogram Data Skor Kemampuan membaca Bahasa Inggris (Y)

Pengolahan data dilanjutkan dengan pengujian hipotesis. Uji hipotesis dilakukan untuk mengetahui apakah terdapat pengaruh ataupun interaksi dari media film dengan strategi semantic mapping. Perhitungan hipotesis dilakukan dengan ANAVA dua jalur dan diperoleh hasil sebagai berikut; pada kelompok media film diketahui nilai $f_{\text {hitung }}>f_{\text {table }}$ atau 7,438 $>3,148$ dengan nilai sig $0,007<0,05$. Maka dapat disimpulkan terdapat peningkatan atau pengaruh pembelajaran dengan menggunakan media film terhadap peningkatan kosakata bahasa Inggris mahasiswa. Berikutnya pada kelompok strategi semantic mapping yang kemudian diketahui nilai $f_{\text {hitung }}>f_{\text {table }}$ atau 27,366 $>3,148$ dengan nilai signifikansi atau sig $0,000<0,05$. Maka dapat disimpulkan terdapat peningkatan atau pengaruh pembelajaran dengan menggunakan strategi semantic mapping terhadap peningkatan kosakata bahasa Inggris mahasiswa. Selanjutnya hasil perhitungan pengujian linieritas garis regresi hubungan antara variabel $\mathrm{X}_{1}$ dengan variabel $\mathrm{Y}$ bisa dilihat pada table berikut: 
Tabel 2

Hasil Pengujian Linieritas Regresi Pengaruh Variabel $X_{1}$ terhadap Variabel $Y$

\begin{tabular}{|c|c|c|c|c|c|c|c|}
\hline \multicolumn{8}{|c|}{ ANOVA Table } \\
\hline & & & $\begin{array}{l}\text { Sum of } \\
\text { Squares }\end{array}$ & $\mathrm{df}$ & $\begin{array}{l}\text { Mean } \\
\text { Square }\end{array}$ & $\mathrm{F}$ & Sig. \\
\hline \multirow{5}{*}{$\begin{array}{l}\text { Kemampuan } \\
\text { Membaca } \\
\text { Bahasa } \\
\text { Inggris * } \\
\text { Minat Belajar }\end{array}$} & \multirow{3}{*}{$\begin{array}{l}\text { Between } \\
\text { Groups }\end{array}$} & (Combined) & 11012,303 & 34 & 323,891 & 3,988 &, 000 \\
\hline & & Linearity & 7881,251 & 1 & 7881,251 & 97,034 & ,000 \\
\hline & & $\begin{array}{l}\text { Deviation from } \\
\text { Linearity }\end{array}$ & 3131,052 & 33 & 94,880 & 1,168 &, 348 \\
\hline & \multicolumn{2}{|c|}{ Within Groups } & 2030,547 & 25 & 81,222 & & \\
\hline & \multicolumn{2}{|l|}{ Total } & 13042,850 & 59 & & & \\
\hline
\end{tabular}

Pada tabel 2 di atas terlihat bahwa nilai pada kolom Sig baris Deviation from Linierity adalah 0,348 >0,05. Hal ini menunjukan bahwa variabel persepsi siswa atas kemmapuan mengajar guru dengan kemampuan membaca Bahasa inggris mempunyai hubungan yang linear. Selanjutnya hasil perhitungan koefisien

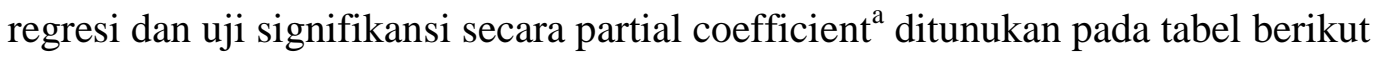

Tabel 3

Hasil Perhitungan Koefisien Regresi dan Uji Signifikansi secara Partial

\begin{tabular}{|c|c|c|c|c|c|}
\hline \multicolumn{6}{|c|}{ Coefficients $^{\mathrm{a}}$} \\
\hline \multirow[t]{3}{*}{ Model } & \multirow{2}{*}{\multicolumn{2}{|c|}{$\begin{array}{l}\text { Unstandardized } \\
\text { Coefficients }\end{array}$}} & Standardized & $\mathrm{t}$ & Sig. \\
\hline & & & Coefficients & & \\
\hline & $\mathrm{B}$ & Std. Error & Beta & & \\
\hline (Constant) & $-3,186$ & 6,194 & &,- 514 & 609 \\
\hline Minat Belajar & ,261 &, 112 & ,244 & 2,323 &, 024 \\
\hline
\end{tabular}

Dependent Variable: Kemampuan Membaca Bahasa Inggris

Berdasarkan angka statistik pada tabel 3 di atas menunjukan bahwa nilai Sig $=0,024<0,05$ dan $t_{\text {Hitung }}=2,323$. Hal ini menunjukan $\mathrm{H}_{0}$ ditolak atau $\mathrm{H}_{1}$ diterima. Artinya hipotesis penelitian dapat diterima. Kesimpulannya, terdapat pengaruh yang signifikan minat belajar terhadap kemampuan membaca Bahasa Inggris.

\section{SIMPULAN}

Berdasarkan hasil penelitian yang telah dilakukan dapat disimpulkan bahwa terdapat pengaruh yang signifikan minat belajar dan penguasaan kosakata secara bersama-sama terhadap kemampuan membaca Bahasa inggris SMK Swasta di Depok. 


\section{DAFTAR PUSTAKA}

Arikunto, S. (2010). Prosedur Penelitian: Suatu Pendekatan Praktek. Rineka Cipta: Jakarta.

Dimyati \& Mudjiono. (2002). Belajar dan Pembelajaran. Rineka Cipta: Jakarta.

Djamarah, S.,B. (2002). Strategi Belajar Mengajar. Rineka Cipta: Jakarta.

Hapsari, S.,F. (2015). The Effect of Reading Habit and Vocbulary Mastery towards Hortatory Expository Writing Skill. Faktor Jurnal Ilmiah Kependidikan. 2(3) LPPM Unindra, Jakarta.

Pratiwi, V.,U. (2015). Kemampuan Membaca Teks Bahasa Inggris. Journal of Magister Scientiae. Edisi no 38 r. Fakultas Keguruan dan Ilmu Pendidikan Universitas Katolik Widya Mandala, Surabaya.

Sugiono. (2013). Metode Penelitian Pendekatan Kualitatif Kuantitatif dan R\&D. Alfabeta: Bandung.

Syah, M. (2003). Psikologi Pendidikan dengan pendekatan baru. PT Remaja Rosdakarya: Bandung.

Usman, U. (2003). Menjadi Guru Profesional. PT Remaja Rosdakarya: Bandung. 